\title{
Characterization of Bentonite Modified by Manganese Oxides
}

\author{
Tomáš Schütz*, Silvia Dolinská, Annamária Mockovčiaková \\ Institute of Geotechnics, Slovak Academy of Sciences, Watsonova 45, 04353 Košice, Slovak Republic \\ *Corresponding Author: schutz@saske.sk
}

Copyright $@ 2013$ Horizon Research Publishing All rights reserved.

\begin{abstract}
The work focuses at the option to improve the sorption properties of bentonite via its modification and presents the possibility to remove heavy metal cations from the water solutions by the usage of non-homogenous bentonite coated by manganese oxides. At first, natural bentonite was converted to its sodium form using $\mathrm{Na}_{2} \mathrm{CO}_{3}$ as the activating agent. Afterwards, manganese oxides precipitated on the surface of natural and sodium activated bentonite, respectively. The structure of the bentonite before and after its modification was subsequently studied by X-ray diffraction analysis. The thermal stability of the natural and modified bentonite was evaluated based on TG and DTA measurements. The morphology of the samples was observed by scanning electron microscope. The zeta potential measurements showed the electrokinetic properties of the bentonites after the precipitation of manganese oxides on their surface. Batch sorptions of $\mathrm{Cd}^{2+}$ from aqueous solutions were conducted to compare the sorption properties of the natural and modified bentonite.
\end{abstract}

Keywords Bentonite, Manganese Oxide, Adsorption

\section{Introduction}

The contamination of water by heavy metals from the industrial wastewater is a worldwide environmental problem. These heavy metals, such as cadmium, may come from various industrial sources, e.g. electroplating, metal finishing, metallurgy and chemical manufacturing. The cadmium colors are added to the paint, rubber, textiles, glass and ceramics. Cadmium is also used in the production of electrodes of alkaline batteries, rechargeable cadmium batteries, semiconductors and photocells. Cadmium is soluble in aquatic conditions, reacts with surrounding elements and transforms into different compounds. It accumulates in the bodies of fish and other aquatic organisms and plants. Human health is at risk through the consumption of contaminated food and water. Adsorption process provides an attractive alternative treatment in comparison with other removal techniques because it is more economical and readily available. Some natural materials such as clays are being considered as alternative low-cost adsorbents [1]. Bentonite is one of the most popular clay rocks with exceptional adsorption properties. The main clay mineral present in bentonite is montmorillonite which belongs to the smectite mineral group. The properties of bentonite result from the crystal structure of this group. The particles of montmorillonite have negative charges on their faces due to the isomorphic substitutions in its structure. This negative charge is compensated by the presence of the cations in the interlayer space, which are not fixed and have the character of so called "exchangeable cations" (i.e. $\mathrm{Na}^{+}$, $\mathrm{K}^{+}, \mathrm{Li}^{+}, \mathrm{Mg}^{2+}, \mathrm{Ca}^{2+}$ ) [2]. This study focused on the preparation of composites containing either natural or natrified bentonite and manganese oxides. The immobilization of manganese oxides on bentonite surface could lead to the improvement of the bentonite sorption properties and also to overcome the limits to the use of pure manganese oxides as adsorbents due to the e.g. economic reasons. Normally, manganese oxides can adopt different structures such as $\mathrm{MnO}_{2}, \mathrm{Mn}_{2} \mathrm{O}_{3}$ and $\mathrm{MnO}$ in which the oxidation states of $\mathrm{Mn}$ are $+4,+3$ and +2 , respectively [3]. The most common form of manganese oxides in nature are poorly crystalline materials like birnessite or vernadite [4]. The natural birnessite in soils and sediments is characterized by unique cation exchange capacity and sorptive, catalytic and oxidative properties [5]. The structure of natural birnessite mineral normally contains foreign ions such as $\mathrm{Na}^{+}, \mathrm{K}^{+}, \mathrm{Ca}^{2+}$ but these are not essential. The synthetic birnessite (birnessite-type manganese oxide or manganous-manganite or $\delta-\mathrm{MnO}_{2}$ ) can be prepared free from foreign ions [6]. The birnessite-type manganese oxide is a layer structured material with a basal spacing of about $0.7 \mathrm{~nm}$, containing edge-shared $\mathrm{MnO}_{6}$ octahedral separated from each other by exchangeable cations such as potassium or water molecules located in the interlayer space [5]. The most common method for synthesis of $\delta-\mathrm{MnO}_{2}$ is the oxidation of manganous hydroxide or the reduction of the potassium permanganate, using a variety of oxidizing or reducing agents [6]. 


\section{Materials and Methods}

The bentonite used in this study originated from the Slovak deposit Stará Kremnička - Jelšový potok. This natural bentonite (B) contains almost monomineral fraction of montmorillonite $(>90 \%)$ with the particles size below 20 $\mu \mathrm{m}$ [7]. The particular amount of natural bentonite was converted to its monoionic sodium form. The natrified bentonite $(\mathrm{NaB})$ was prepared from the slurry, which contained the activating agent $\left(\mathrm{Na}_{2} \mathrm{CO}_{3}\right)$ and distilled water to which the bentonite was added. The stabilization took 24 hours at ambient temperature. The final product was dried at $60{ }^{\circ} \mathrm{C}$ and then it was mashed manually. Subsequently, the manganese oxide - natural bentonite composite (Mn-B), manganese oxide - natrified bentonite composite $(\mathrm{Mn}-\mathrm{NaB})$ and reference sample of "pure" manganese oxides (Ref-Mn) were prepared via precipitation [8] represented by the reaction (1):

$$
2 \mathrm{KMnO}_{4}+8 \mathrm{HCl} \rightarrow 2 \mathrm{MnO}_{2}+2 \mathrm{KCl}+3 \mathrm{Cl}_{2}+4 \mathrm{H}_{2} \mathrm{O}(1)
$$

The Mn-B and Mn-NaB were prepared in the weight ratio 1:1 (bentonite : manganese oxides). Ref-Mn was prepared without the addition of bentonites. The process of manganese oxides precipitation included these steps: Potassium permanganate was dissolved in distilled water in a beaker and kept in the $90{ }^{\circ} \mathrm{C}$ water bath for 15 minutes. Then bentonite was added into the purple solution and this suspension was mixed gently for 10 minutes. After that, $2 \mathrm{M}$ $\mathrm{HCl}$ were slowly added dropwise to the suspension and heated in the $90{ }^{\circ} \mathrm{C}$ water bath. After titration, the mixture was stirred for further 30 minutes. The final product was cooled at the air and washed several times using double distilled water, then dried in the oven at $100{ }^{\circ} \mathrm{C}$ for 24 hours and stored. X-Ray diffraction data were obtained by the diffractometer Bruker D8 Advance $(40 \mathrm{kV}, 40 \mathrm{~mA})$, working with the $\mathrm{CuK} \alpha$ radiation. JCPDS (Joint Committee for Powder Diffraction Data - International Centre for Diffraction Data) database was used to analyze the diffraction peaks. Thermal analyses (TG and DTA) were carried out at temperature up to $800{ }^{\circ} \mathrm{C}$ in air using NETZSCH STA 449 F1 Jupiter instrument under these conditions: sample weight $200 \mathrm{mg}$, heating rate $10{ }^{\circ} \mathrm{C} / \mathrm{min}$, and $\mathrm{Al} 2 \mathrm{O} 3$ crucible. The electrokinetic properties of the particles in the aqueous solutions played a significant role in understanding of the adsorption properties at the solid solution interface [9]. Zeta potential measurements were carried out by Malvern Zetasizer Nano Z, which works with the technique of the laser doppler electrophoresis. The changes in the surface charge were determined as a function of $\mathrm{pH}$. The initial suspensions having different $\mathrm{pH}$ values were prepared by the addition of $\mathrm{NaOH}$ and $\mathrm{HNO}_{3}$. The morphological overview of the investigated samples was obtained by the field emission scanning electron microscope TESCAN MIRA 3 FE SEM with the accelerating voltage of $20 \mathrm{kV}$. The particles were examined at several magnifications. The sorption properties of the selected samples were examined by the sorption of cadmium cations from the synthetic solution $\mathrm{Cd}\left(\mathrm{NO}_{3}\right)_{2} \cdot 4 \mathrm{H}_{2} \mathrm{O}$ at ambient temperature. The initial concentrations of $\mathrm{Cd}^{2+}$ were in the range from 10 to $700 \mathrm{mg} / \mathrm{L}$. The concentration of adsorbent was $1 \mathrm{~g} / \mathrm{L}$. The sorption was done in polyethylene tubes on the rotary shaker, $\mathrm{pH}$ of the solution with the help of $\mathrm{NaOH}$ and $\mathrm{HNO}_{3}$ was set to 5. Shaking was in progress for 24 hours. The concentration of the metals was determined by the method of atomic adsorption spectroscopy (Varian 240 $\mathrm{RS} / 2400$ ).

\section{Results and Discussion}

The X-ray diffraction analysis of natural bentonite (B) confirmed montmorillonite as dominant mineral phase (Figure 1a). The activation of bentonite by sodium cations caused structural changes in the natural bentonite (Figure 1b). It affected mainly (001) the reflection of montmorillonite. The shift of (001) reflection of $\mathrm{NaB}$ to the right on $\mathrm{x}$ axis points to the cation exchange from interlayer space for cations with the smaller atomic radius. Moreover, after the natrification, (003) reflection of montmorillonite disappeared and the intensities of the (100) and (110) reflections were reduced. Reference sample of manganese oxides with the strongest reflection of $d_{001}$ value of $0.717 \mathrm{~nm}$ (Figure 1c) corresponds to birnessite-type manganese oxide according to the X-ray diffraction analysis published by many authors $[10,11]$. Precipitation of manganese oxides on bentonite caused structural changes in both composites $\mathrm{Mn}-\mathrm{B}$ and $\mathrm{Mn}-\mathrm{NaB}$. The main (001) reflection of montmorillonite was reduced and (005) reflection disappeared (Figure $1 \mathrm{~d}, \mathrm{e}$ ). On the other side, (001), (002), (200) and (310) reflections of birnessite-type manganese oxide appeared in diffraction patterns of $\mathrm{Mn}-\mathrm{B}$ and $\mathrm{Mn}-\mathrm{NaB}$ (Figure $1 \mathrm{~d}, \mathrm{e}$ ). However, $\mathrm{d}_{001}$ value of manganese oxides shifted from $0.717 \mathrm{~nm}$ to $0.705 \mathrm{~nm}$ in diffraction patterns of $\mathrm{Mn}-\mathrm{B}$ and $0.701 \mathrm{~nm}$ in diffraction patterns of $\mathrm{Mn}-\mathrm{NaB}$ and $\mathrm{d}_{002}$ value from $0.366 \mathrm{~nm}$ to $0.352 \mathrm{~nm}(\mathrm{Mn}-\mathrm{B})$ and $0.354 \mathrm{~nm}$ $(\mathrm{Mn}-\mathrm{NaB})$, respectively. These changes can probably be associated with the ability of the montmorillonite to exchange cations from water solutions. The impact of the ion exchange of manganese cations on the structural changes of composites is going to be studied later. 


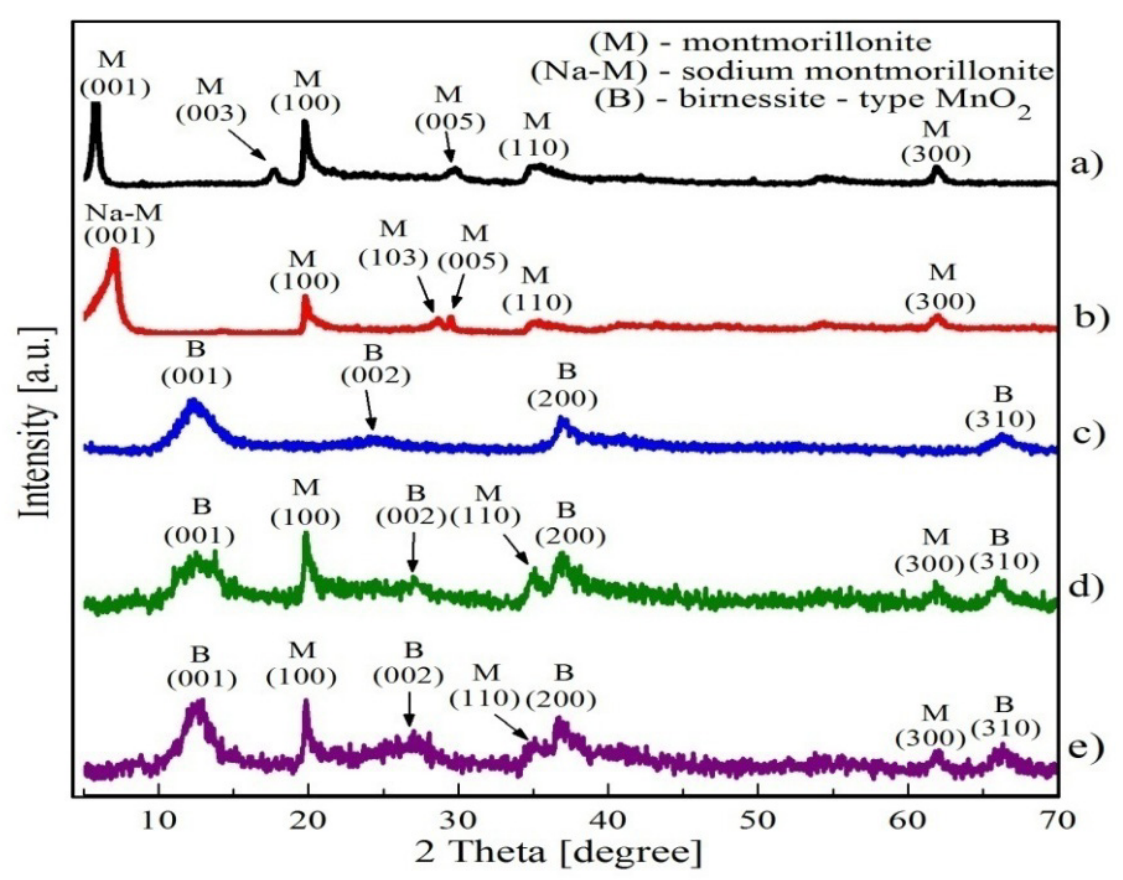

Figure 1. X-ray diffraction patterns of the B (a), NaB (b), Ref-Mn (c), Mn-B (d) and Mn-NaB (e)

The thermal studies of natural bentonite are shown in Figure 2. The first dominant mass loss of natural bentonite was due to the dehydration of interparticle water, adsorbed water and interlayer water. The DTA doubled endothermic peak that corresponded to this change was observed at around 137 and $195{ }^{\circ} \mathrm{C}$ (Figure 2). The endothermic peak with its maximum at about $690{ }^{\circ} \mathrm{C}$ was related to the release of $\mathrm{OH}$ groups from the octahedral layer [12]. The first step in the thermal decomposition of reference sample of birnessite-type manganese oxide (Ref-Mn) linked with the loss of adsorbed water. The exothermic peak at around $540{ }^{\circ} \mathrm{C}$ on DTA curve may be attributed to the phase transformation caused by the formation of $\mathrm{Mn}_{2} \mathrm{O}_{3}$ and cryptomelane (Figure 4) [13]. The main weight losses of $\mathrm{Mn}-\mathrm{B}$ and $\mathrm{Mn}-\mathrm{NaB}$ (Figure 5,6) were related to the decrease of adsorbed water below $150{ }^{\circ} \mathrm{C}$. TG curve of $\mathrm{Mn}-\mathrm{NaB}$ (Figure 6) showed the higher mass stability in the temperature range from 200 to $800^{\circ} \mathrm{C}$ than in the case of Ref-Mn (Figure 4).

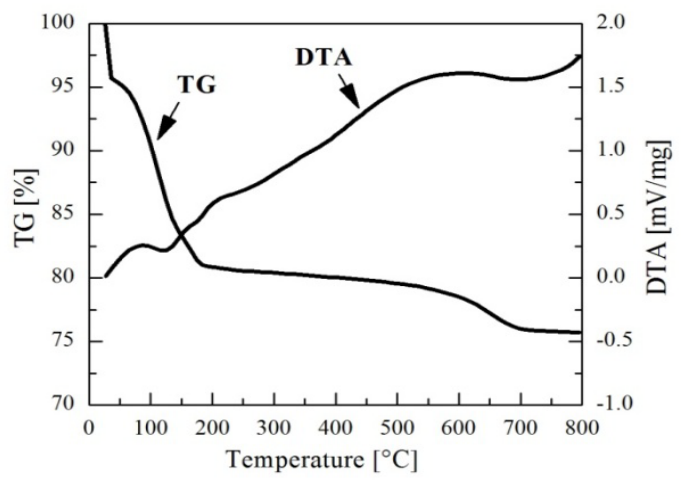

Figure 2. TG and DTA curves of B

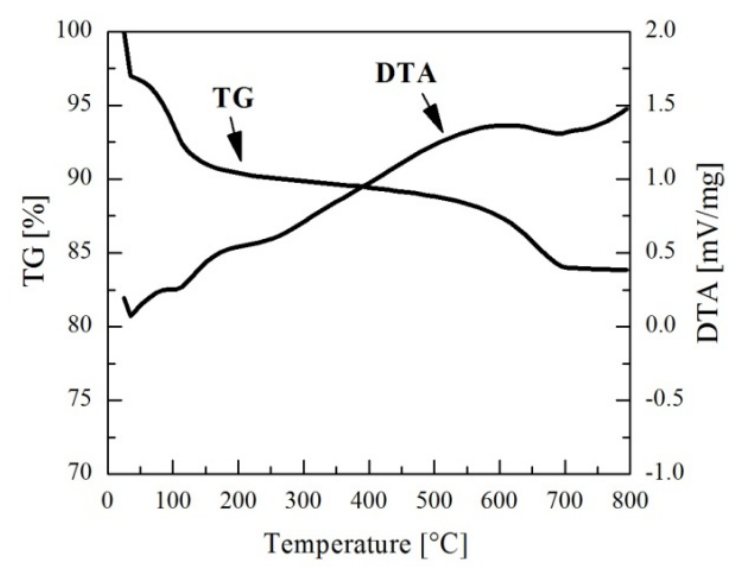

Figure 3. TG and DTA curves of $\mathrm{NaB}$

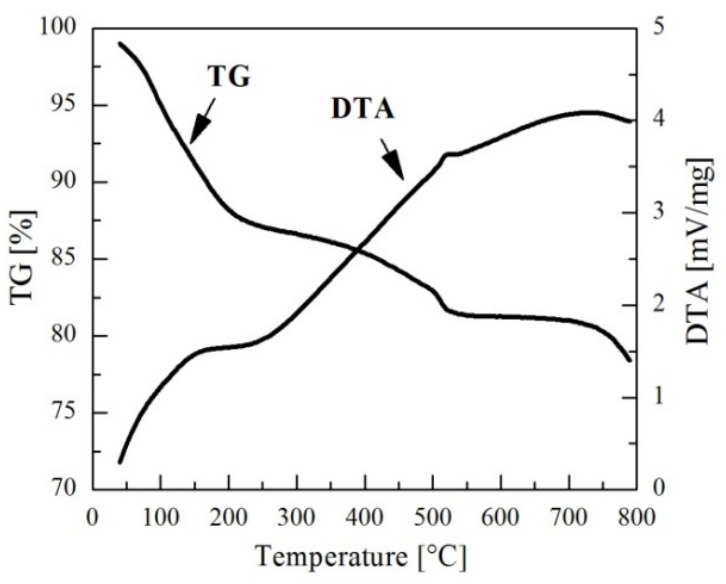

Figure 4. TG and DTA curves of Ref-Mn 


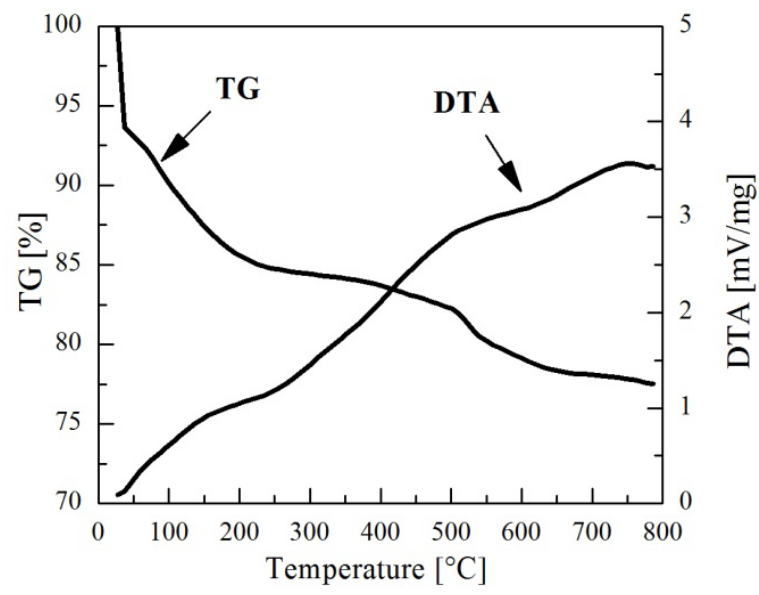

Figure 5. TG and DTA curves of Mn-B

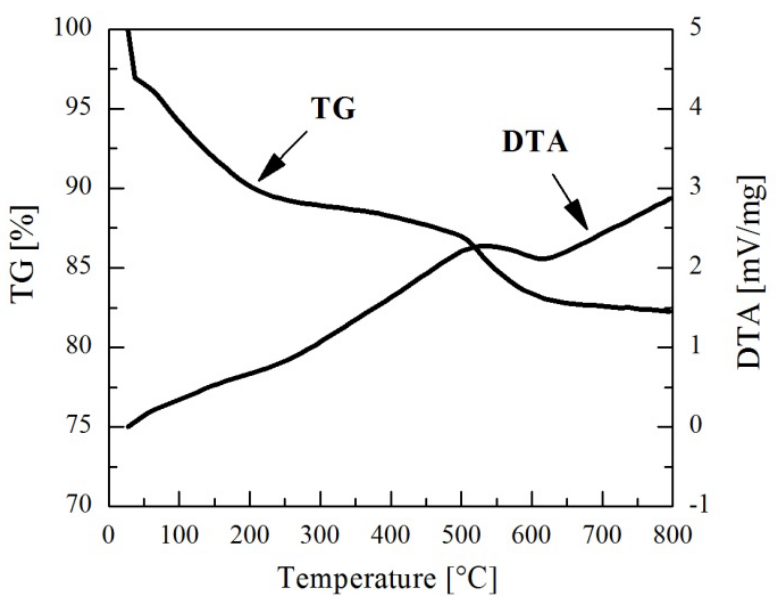

Figure 6. TG and DTA curves of $\mathrm{Mn}-\mathrm{NaB}$

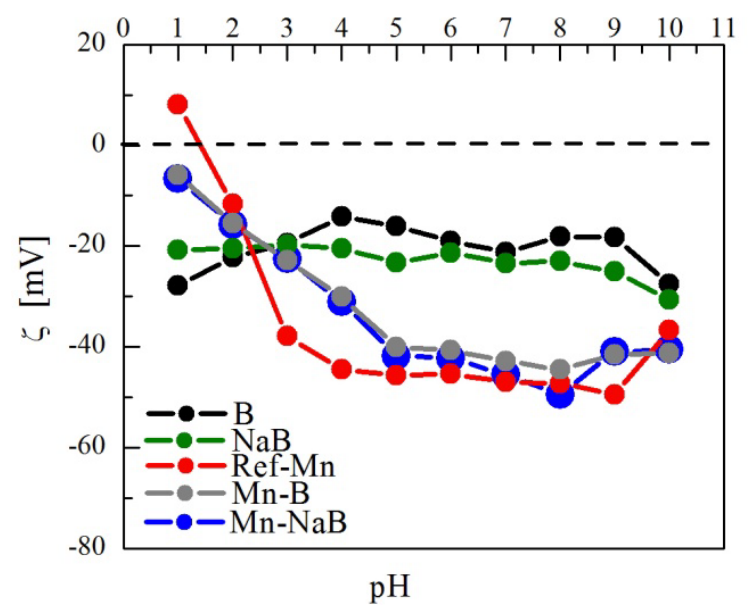

Figure 7. Zeta potential as a function of $\mathrm{pH}$

The zeta potential values $(\zeta)$ measured for each final $\mathrm{pH}$ value of suspensions are shown in Figure 7. The isoelectric point for natural bentonite was not reached. The reason is in the nonstoichiometric substitutions of $\mathrm{Al}$ for $\mathrm{Si}$ in the tetrahedral sheets and $\mathrm{Mg}$ for $\mathrm{Al}$ in the octahedral sheets of the 2:1 layered structure of montmorillonite. The saturation of bentonite with the sodium cations within the $\mathrm{NaB}$ sample did not have a significant effect on the zeta potential values of bentonite, which remained negative during the whole measurement (Figure 7). With the increase in $\mathrm{pH}(>3)$, absolute values of zeta potential of Ref-Mn, Mn-B and $\mathrm{Mn}-\mathrm{NaB}$ were overall higher than in the case of natural (B) and natrified bentonite $(\mathrm{NaB})$ (Figure 7). Ref-Mn changed zeta potential from negative to positive values at $\mathrm{pH} \approx 1.5$. The composites (Mn-B and $\mathrm{Mn}-\mathrm{NaB}$ ) did not achieve zero values of zeta potential and showed higher stability than Ref-Mn in the whole $\mathrm{pH}$ range.

Figures 8-10 show SEM images of $\mathrm{B}, \mathrm{NaB}$, Ref-Mn, $\mathrm{Mn}-\mathrm{B}$ and $\mathrm{Mn}-\mathrm{NaB}$. The activation of natural bentonite with sodium did not lead to significant change in its morphology (Figure 8b). The SEM analysis of Ref-Mn pointed on clusters of spherical shaped objects with a diameter of 1-2 $\mu \mathrm{m}$ and so-called sea urchin nanostructure (Figure 9). The sea urchin-like structure was composed of many flakes radiating from its center. The flakes corresponded to the very thin nanowall sheets with the thickness of several to ten nanometers [5]. The study of $\mathrm{Mn}-\mathrm{B}$ and $\mathrm{Mn}-\mathrm{NaB}$ morphology showed that manganese oxides precipitated on bentonites surface unevenly (Figures 10a, b).
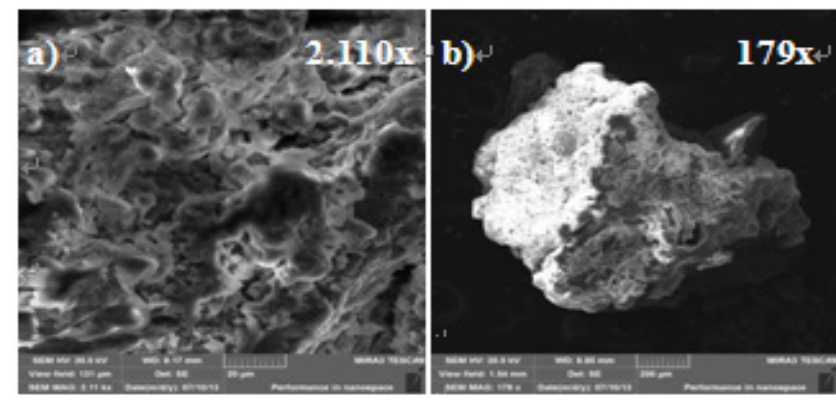

Figure 8. $\quad$ SEM images of $\mathrm{B}(\mathrm{a}), \mathrm{NaB}(\mathrm{b})$

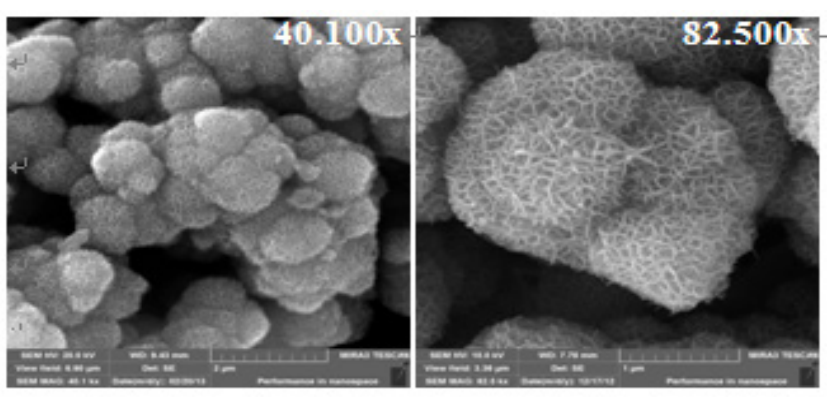

Figure 9. SEM images of Ref-Mn
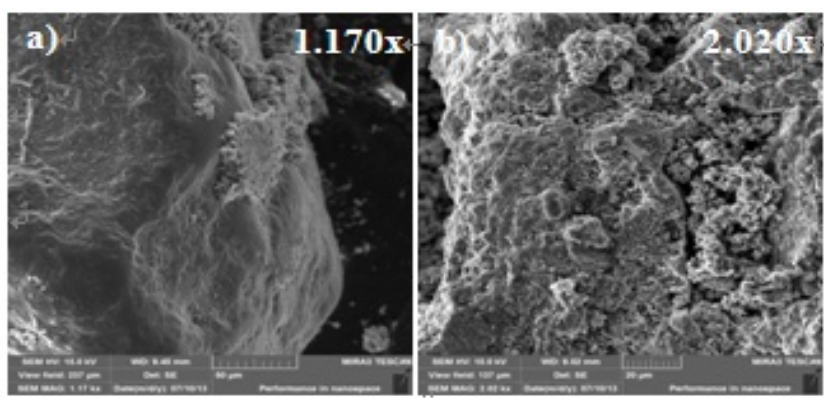

Figure 10. SEM images of Mn-B (a), Mn-NaB (b) 
The last but very important step in this study was the comparison of sorption properties of bentonite before and after its modifications. To investigate the effect of $\mathrm{Cd}^{2+}$ solution $\mathrm{pH}$ on the sorption, the $\mathrm{pH}$ values were set up to the range of $2-9$ (Figure 11). The cadmium uptake over this $\mathrm{pH}$ range was studied with the initial metal concentration -100 $\mathrm{mg} / \mathrm{L}$. Adsorption capacity of cadmium removal for all investigated sorbents was found stable at $\mathrm{pH} 5-6$ [14]. The higher uptakes at $\mathrm{pH}$ above 7 are ascribed to the precipitation of hydroxides [15]. The sorption kinetics was analyzed in terms of pseudo-first-order and pseudo-second-order kinetic models. The correlation coefficients for the second-order kinetic model were higher than for the first-order in all samples. This indicates that the second - order model is more suitable to describe the sorption kinetics of the $\mathrm{Cd}^{2+}$ removal by natural and modified bentonites. The linear form of second - order kinetics (Figure 12) shows the plot of $t / \mathrm{q}_{\mathrm{t}}$ versus time (2).

$$
\frac{t}{q_{t}}=\frac{1}{k q_{e}{ }^{2}}+\frac{t}{q_{e}},
$$

where $k$ represents the rate constant of the sorption and $q_{e}$ is the amount of the adsorbed species at equilibrium [16]. Table 1 summarizes the results of sorption kinetics and shows a good agreement between experimental and calculated values of $q_{e}$. Figure 13 shows the isotherms of $\mathrm{Cd}^{2+}$ sorption on the natural bentonite $(\mathrm{B})$ and modified samples $(\mathrm{NaB}),(\mathrm{Mn}-\mathrm{B})$ and (Mn-NaB). The sorption data were fitted with the help of linear shape of Langmuir isotherm (3) [17]:

$$
\frac{C_{e}}{q_{e}}=\frac{1}{Q_{m} b}+\frac{C_{e}}{Q_{m}},
$$

where $\mathrm{Ce}$ is the equilibrium concentration of the metal ions in the solution, $q e$ is the amount of the adsorbed metal related to the weight unit of the adsorbent (mg/g), $Q m$ represents the maximal adsorption capacity $(\mathrm{mg} / \mathrm{g})$ and $b$ is the sorption equilibrium constant $(\mathrm{L} / \mathrm{mg})$. The values of Langmuir parameters for the sorption of $\mathrm{Cd}^{2+}$ cations are given in Table 2.

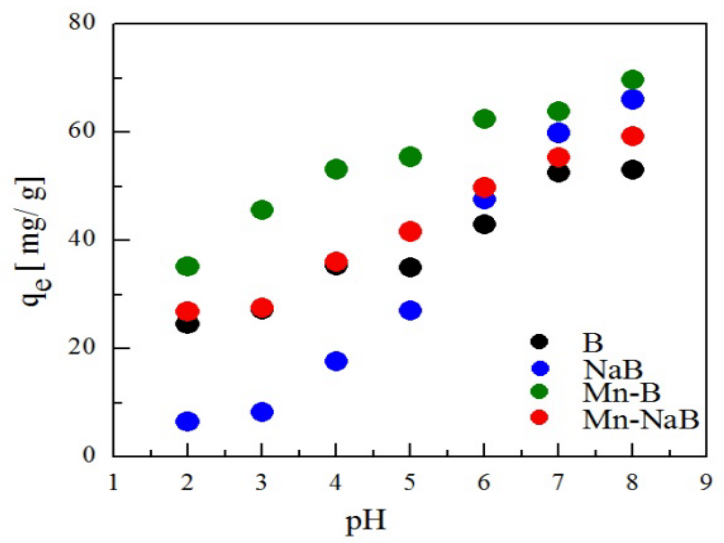

Figure 11. Effect of solution $\mathrm{pH}$ on $\mathrm{Cd}^{2+}$ removal

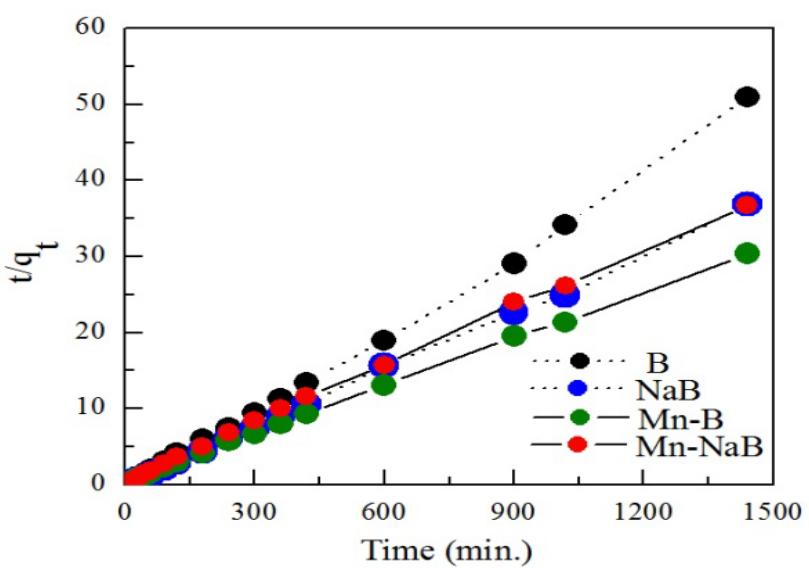

Figure 12. Pseudo - secon-order kinetic model for $\mathrm{Cd}^{2+}$ removal

Table 1. Kinetic parameters for sorption of $\mathrm{Cd}^{2+}$

\begin{tabular}{|c|c|c|c|c|}
\hline Sample & $\begin{array}{c}\text { qe (exp) } \\
{[\mathrm{mg} / \mathrm{g}]}\end{array}$ & $\begin{array}{c}\mathrm{qe}(\mathrm{cal}) \\
{[\mathrm{mg} / \mathrm{g}]}\end{array}$ & $\begin{array}{c}\mathrm{k} \\
{[\mathrm{g} / \mathrm{mg} \min ]}\end{array}$ & $\mathrm{R}^{2}$ \\
\hline $\mathrm{B}$ & 28.24 & 31.64 & 0.088 & 0.9971 \\
\hline $\mathrm{NaB}$ & 39.06 & 40.16 & 0.026 & 0.9993 \\
\hline $\mathrm{Mn}-\mathrm{B}$ & 47.36 & 47.61 & 0.001 & 0.9994 \\
\hline $\mathrm{Mn}-\mathrm{NaB}$ & 39.22 & 39.21 & 0.001 & 0.9991 \\
\hline
\end{tabular}

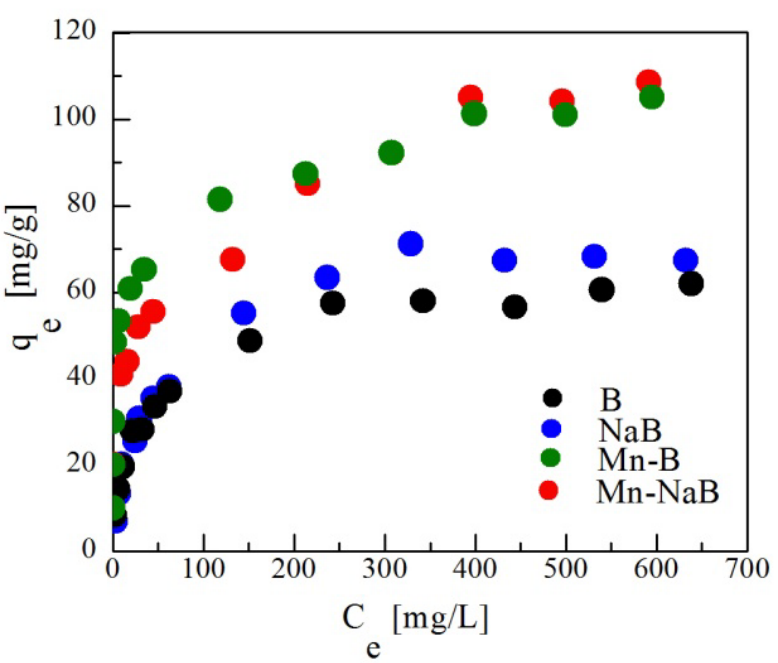

Figure 13. Sorption of $\mathrm{Cd}^{2+}$ on $\mathrm{B}, \mathrm{NaB}, \mathrm{Mn}-\mathrm{B}$ and $\mathrm{Mn}-\mathrm{NaB}$

Table 2. Langmuir parameters for sorption of $\mathrm{Cd}^{2+}$

\begin{tabular}{|c|c|c|c|}
\hline Sample & Qm $[\mathrm{mg} / \mathrm{g}]$ & $\mathrm{b}[\mathrm{L} / \mathrm{mg}]$ & $\mathrm{R}^{2}$ \\
\hline $\mathrm{B}$ & 63.29 & 0.032 & 0.9967 \\
\hline $\mathrm{NaB}$ & 72.99 & 0.027 & 0.9967 \\
\hline $\mathrm{Mn}-\mathrm{B}$ & 103.09 & 0.083 & 0.9948 \\
\hline $\mathrm{Mn}-\mathrm{NaB}$ & 108.69 & 0.038 & 0.9847 \\
\hline
\end{tabular}

Natrification of bentonite best enables the division of the basic montmorillonite layers which provides new space for adsorption of cadmium cations and leads to the increase in the overall adsorption capacity [18]. The increment of 
cation exchange capacity after the natrification was confirmed by previous experiments [19]. The synthetic birnessite precipitated on bentonite particles resulted in the surface charge reduction of modified bentonites (zeta potential measurements results). The cause of this phenomenon is the net negative layer charge of birnessite structure where $\mathrm{Mn}^{3+}$ or vacancies substitute for $\mathrm{Mn}^{4+}$ in the octahedral layers. It leads to higher cadmium cations interaction with the surface of $\mathrm{MnO}_{2}$ - modified bentonites where the cadmium adsorption takes place on the two separated structures: the first one is, the electrostatic adsorption on basal sheets of montmorillonite structure and chemisorption through the amphoteric ligands on edges of clay minerals [20]; and the second one is the ion exchange between $\mathrm{K}^{+}$or $\mathrm{Na}^{+}$and $\mathrm{Cd}^{2+}$ in the interlayer space of birnessite - type manganese oxide structure.

\section{Conclusion}

The modification of bentonite resulted in the non-homogeneous covering by manganese oxides. The manganese oxides precipitated on the surface of bentonite were identified as birnessite-type manganese oxides by the X-ray diffraction analysis. The scanning electron microscopy showed that these manganese oxides formed urchin-like structured particles. From the sorption experiments, $\mathrm{Mn}-\mathrm{NaB}$ reached the highest value of maximum adsorption capacity.

\section{Acknowledgements}

This work was supported by the Slovak Grant Agency for Science VEGA No. 2/0115/12 and 2/0114/13 and the projects NanoCEXmat I (26220120019) and NanoCEXmat II (26220120035).

\section{REFERENCES}

[1] S. Babel, T. Kurniawan. Low-cost Adsorbents for Heavy Metals Uptake from Contaminated Water: a review, Journal of Hazardous Materials, Vol. 97, No. 1-3, 219-243, 2003.

[2] M.Galamboš, J. Kufčáková, O. Rosskopfová, P. Rajec. Adsorption of Cesium and Strontium on Natrified Bentonites, Journal of Radioanalytical and Nuclear Chemistry, Vol. 283, No. 3, 803-813, 2010.

[3] D. Frías, S. Nousir, I. Barrio, M. Montes, T. López, M. Centeno, J. Odriozola. Synthesis and Characterization of Cryptomelane - and Birnessite-type Oxides: Precursor effect, Materials Characterization, Vol. 58, No. 8-9, 776-781, 2007.

[4] S. Taffarel, J. Rubio. Removal of $\mathrm{Mn} 2+$ from Aqueous Solution by Manganese Oxide Coated Zeolite. Minerals Engineering, Vol. 23, No. 14, 1131-1138, 2010.

[5] H. Zhu, J. Luo, H. Yang, J. Liang, G. Rao, J. Li, Z. Du.
Birnessite-type $\mathrm{MnO}_{2}$ Nanowalls and Their Magnetic Properties, Journal of Physical Chemistry C, Vol. 112, No. 44, 17089-17094, 2008.

[6] R. McKenzie. Synthesis of Birnessite, Cryptomelane, and some other Oxides and Hydroxides of Manganese, Mineralogical Magazine, Vol. 38, 493-502, 1971.

[7] J. Jesenák, V. Hlavatý. Laboratory Device for Sedimentation of fine Bentonite Fractions, Scripta Facultatis Scientiarum Naturalium Universitatis Masarykianae Brunensis Geology, Vol. 28-29, 33-36, 2000.

[8] W. Cole, A. Wadsley, A. Walkley. An X - Ray Diffraction Study of Manganese Dioxide, Journal of The Electrochemical Society, Vol. 92, No. 1, 133-158, 1947.

[9] O. Duman, S. Tunç. Electrokinetic and Rheological Properties of Na-bentonite in some Electrolyte Solutions, Microporous and Mesoporous Materials, Vol. 117, No. 1-2, 331-338, 2009.

[10] S. Tu, G. Racz, T. Goh. Transformations of Synthetic Birnessite as affected by $\mathrm{pH}$ and Manganese Concentration, Clays and Clay Minerals, Vol. 42, No. 3, 321-330, 1994.

[11] M. Cheney, P. Bhowmik, S. Qian, S., Joo, S., W. Hou, J. Okoh. A New Method of Synthesizing Black Birnessite Nanoparticles: From Brown to Black Birnessite with Nanostructures, Journal of Nanomaterials, Vol. 2008, 1-9, 2008.

[12] M. Önal, Y. Sarikaya. Thermal Behaviour of a Bentonite, Journal of Thermal Analysis and Calorimetry, Vol. 90, No. 1, $167-172,2007$.

[13] K. Ramalingam, T. Kamatchi, P. Sumod. Synthesis, Spectral, Thermal and $\mathrm{CO}_{2}$ Absorption Studies on Birnessites Type layered $\mathrm{MnO}_{6}$ Oxide, Transition Metal Chemistry, Vol. 31, No. 4, 429-433, 2006.

[14] A. Mockovčiaková, Z. Orolínová, J. Škvarla. Enhancement of the bentonite sorption properties, Journal of Hazardous Materials, Vol. 180, No. 1-3, 274-281, 2010.

[15] A. Özer, H.B. Pirinççi. The adsorption of Cd (II) ions on sulphuric acid-treated wheat bran, Journal of Hazardous Materials, Vol. 137, No. 2, 849-855, 2006.

[16] M.H. Entezari, T.Soltani. Simultaneous removal of copper and lead ions from a binary solution by sono-sorption process, Journal of Hazardous Materials, Vol. 160, No. 1, 88-93, 2008.

[17] I. Langmuir. The Adsorption of Gases on Plane Surfaces of Glass, Mica and Platinum, Journal of the American Society, Vol. 40, No. 9, 1361-1403, 1918.

[18] M. Galamboš, J. Kufčáková, O. Rosskopfová, P. Rajec. Adsorption of cesium and strontium on natrified bentonites, Journal of Radioanalytical and Nuclear Chemistry, Vol. 283, No. 3, 803-813, 2010.

[19] T. Schütz, A. Mockovčiaková, Z. Orolínová, A. Zorkovská, P. Hudec. Activation of natural bentonite from the Slovak deposit, SGEM 2012: Modern Management of Mine Producing, Geology and Environmental Protection, 357-364, 2012.

[20] J. Makovníková, G. Barančíková, P. Dlapa, K. Dercová. Inorganic contaminants in soil ecosystem, Chemické listy, Vol. 100, No. 6, 424-432, 2006. 